\title{
C-Reactive Protein and High Blood Pressure are the Predictive Factors of Deciding the Surgical Treatment in Deep Neck Infection: A Retrospective Cohort Study
}

\author{
Jung Heob Sohn, Bo Young Kim, and Kyoung Rai Cho \\ Department of Otolaryngology-Head and Neck Surgery, Sanggye Paik Hospital, Inje University College of Medicine, Seoul, Korea
}

\begin{abstract}
심경부 감염환자의 수술적 치료 결정의 예측인자로서 C-반응단백과 고혈압의 의의: 후향적 코호트 연구
\end{abstract}

손정협·김보영 · 조경래

인제대학교 의과대학 상계백병원 이비인후과학교실

Received March 8, 2018

Revised April 30, 2018

Accepted May 4, 2018

Address for correspondence

Kyoung Rai Cho, MD, PhD

Department of Otolaryngology-

Head and Neck Surgery,

Sanggye Paik Hospital,

Inje University College of Medicine,

1342 Dongil-ro, Nowon-gu,

Seoul 01757 , Korea

Tel $+82-2-950-1104$

Fax $+82-2-935-6220$

E-mail elysion20@hanmail.net
Background and Objectives In clinical settings, some deep neck infections may be managed by conservative treatment but some still require surgical treatment. In this study, we use univariate and multivariate analysis to discuss whether or not there are significant differences between conservative treatment and surgical treatment on patients with deep neck infections. Subjects and Method We conducted a retrospective analysis using medical records of 88 patients with deep neck infections from January 2010 to December 2015. Among 88 patients, 56 patients were managed by conservative treatment with antibiotics and 32 patients were managed by surgical treatment via transcervical approach with antibiotics. As for data analysis, Mann-Whitney U test and multiple logistic regression analysis was used.

Results Age, duration from symptom onset to hospitalization, hospital days, incidence of underlying disease, white blood cell count, erythrocyte sedimentation rate, and C-reactive protein (CRP) were found higher in the surgical treatment group than in the conservative treatment group. But there was no statistical significance except for the incidence of high blood pressure and CRP.

Conclusion CRP and incidence of high blood pressure were significant predictive factors for choosing the surgical treatment in deep neck infection. Contrary to our expectations, the incidence of diabetes mellitus was not a significant factor that determined the treatment options for the patients with deep neck infection.

Korean J Otorhinolaryngol-Head Neck Surg 2018;61(9):472-7

Key Words Infection $\cdot$ Neck $\cdot$ Regression analysis.

\section{서 론}

심경부 감염은 경강(cervical space) 및 경막면(fascial plane) 에서의 감염을 의미하며, 농양이 형성된 경우나 봉와직염의 경우를 모두 포함한다. 최근 구강 위생의 개선 및 항생제의

This is an Open Access article distributed under the terms of the Creative Commons Attribution Non-Commercial License (https://creativecommons.org/licenses/by-nc/4.0) which permits unrestricted non-commercial use, distribution, and reproduction in any medium, provided the original work is properly cited.
발달로 심경부 감염의 빈도는 많이 줄어들었으나 적절히 치 료되지 않으면 하행성 종격동염, 상기도 폐쇄, 늑막과 폐의 농양, 심낭염, 경정맥 혈전, 파종성 혈관 내 응고증, 패혈증 등 의 심각한 합병증을 유발할 수 있다. ${ }^{1-3)}$ 이러한 합병증들이 생겼을 때는 사망률이 크게 증가하므로 환자의 상태를 정확 하게 파악하여 최선의 치료를 선택하는 것이 매우 중요하 다. ${ }^{3,4}$ 심경부 감염의 치료는 적절한 항생제 사용과 명백한 농 양이 존재할 시에 시행하는 절개 및 배농이 필수적이라 인식 
되어 왔으나 근래에는 항생제의 발달로 조영증강 경부 전산 화단층촬영에서 확인되는 농양이 있는 경우에도 보존적 치 료만으로 완치되는 경우를 임상에서 드물지 않게 경험하고 있다. 저자들은 심경부 감염 환자의 치료 방향을 결정하는 데 도움을 주고자 이전 연구에서 보존적 치료만으로 완치된 환자군과 24 48시간 동안의 보존적 치료에도 임상 증상의 호전이 없어 전신마취하에 경경부 절개를 통해 배농을 시행 했던 환자군을 비교 분석한 연구를 보고하였고, 고혈압과 $\mathrm{C}$-반응단백이 유의하게 영향을 미치지만 당뇨병의 존재는 영향을 미치지 않는다는 결과를 얻었다.) 하지만 이전 연구는 두 군 간의 치료 결과에 영향을 미치는 요인들을 단변량 통계 분석(univariate analysis)을 이용한 연구로 변수들 간의 교란 효과(confounding effect)에 의한 삐뚤림(bias)을 고려하지 않았기에 증례를 모아 다중 회귀 분석(multiple regression analysis)을 시행하여 이전 연구의 통계적인 제한점을 보완하 고자 하였다. 최종적으로 심한 감염과 합병증이 동반되어 조 기 수술이 행해졌던 환자를 제외하고, 영상학적 검사에서 농 양이 확인된 심경부 감염 환자들을 수술적 치료군과 보존적 치료군으로 분리하여 성별, 연령, 증상 발생 후 치료 시작까 지 걸린 시간, 말초 혈액 백혈구 수, 적혈구 침강속도, 기저질 환 유무, $\mathrm{C}$-반응단백 수치를 비교 분석함으로써 임상적 치 료 방향을 결정하는 데 영향을 미치는 유의한 예측 인자가 있는지 알아보고자 하였다.

\section{대상 및 방법}

2010년 1월부터 2015년 12월까지 6년간 병원에 내원하여 치 료한 88명의 심경부 감염 환자들의 진료기록을 대상으로 후향 적 연구를 시행하였고 인제대학교 상계백병원 임상시험심사 위원회(Institutional Review Board)의 승인 후 진행되었다 (IRB No. 2018-02-023). 대상 환자들은 모두 내원 당시 촬 영한 조영증강 경부 전산화단층촬영에서 심경부 농양이 확 인되었다.

심경부 감염이 의심되어 내원하는 환자는 즉시 문진과 이 학적 검사를 통하여 증상과 징후를 파악하였고, 혈액 검사 및 경부 전산화단층촬영을 시행하였다. 경부 전산화단층촬 영에서 심경부 감염으로 진단되면 그람 양성, 그람 음성, 혐 기성 균주에 감수성이 있는 광범위 항생제를 조합하여 정맥 주사하였고 24 48시간 동안 정맥 항생제 치료를 유지한 뒤, 인후통, 연하통, 연하곤란, 발열 등의 증상과 이학적 검사상 의 경부 종창, 인후두 종창, 경부 압통 등의 소견이 명백한 호 전을 보일 경우 보존적 치료군으로 분류하여 항생제 치료를 연장하였다. 그러나 48 시간 내에 임상적인 증상과 이학적 검사
의 호전이 없다고 판단된 경우 경부 전산화단층촬영을 재실 시하고, 영상검사에서 농양과 연부 조직 종창이 호전되지 않 거나 악화된 경우 경경부 절개 하에 수술적 치료를 시행하여 수술적 치료군으로 분류하였다. 이후 두 군 모두에서 환자의 임상 증상이 소실되고 이학적 검사상 급성 염증 소견과 연부 조직 종창 소견이 현저히 호전된 경우 정맥 항생제 복합치료 를 종결하고 경구 항생제로 바꾸어 환자를 퇴원시켰다. 총 88 명의 환자 중 보존적 치료만으로 호전된 경우가 56 명, 수술적 치료를 행한 경우가 32명이었다.

심경부 감염 치료 종결 후 후향적으로 연구가 진행되다 보 니 명확한 연구 대상군을 특정하는 데 어려움이 있었으나 최 종적으로 연구에 포함된 대상은 다음과 같다. 첫째, 경부 전산 화단층촬영에서 명백한 농양이 확인되면서 최대 직경이 $4 \mathrm{~cm}$ 를 넘지 않은 경우, 둘째, 기도 폐쇄, 괴사성 근막염, 종격동 염, 패혈증 등의 심경부 감염의 합병증이 저명하지 않은 경우, 셋째, 명백한 농양에 대한 치료로 광범위 정맥 항생제를 24 48시간 동안 사용할 수 있었던 경우, 넷째, 환자의 기저질 환이 매우 심각하지 않아 내과적으로 2시간 이상의 전신마취 를 시행하기 불가하지 않은 경우, 다섯째, 농양이 편도와 인두 주위, 표피표재성으로 존재하지 않아 절개 배농을 국소마취 하에 진행할 수 없는 경우로 특정되었다.

연구대상 배제 기준으로 편도 주위 농양과 결핵, 외상, 수술 또는 양성종양, 악성종양에 의한 2차 감염은 제외하였고, 농 양이 경부에 표재성으로 존재하여 국소마취하 배농이 용이 한 악하공간, 전경부 공간, 이하선 공간 감염도 제외하였다. 전산화단층촬영에서 확인되는 농양의 최대 직경이 $4 \mathrm{~cm}$ 이 상인 경우, 두 개 이상의 심경부 공간을 침범하면서 염증이 광범위할 경우, 기도 폐쇄와 하행성 종격동염, 괴사성 근막 염, 패혈증 등의 심각한 합병증이 의심되는 경우 또한 조기 에 수술적 치료가 시행되었으므로 대상에서 제외되었다.

두 군을 대상으로 성별, 연령, 증상 발생 후 치료 시작까지 걸린 시간, 말초 혈액 백혈구 수, 적혈구 침강속도, 기저질환 유무, C-반응단백 수치를 비교 분석하였으며 이는 내원 당 일 실시한 혈액 검사를 기초로 하였다. 심경부 감염의 원인 균주에 대한 비교는 시행하지 않았는데 보존적 치료군에서 는 원인균 동정에 필요한 검체를 얻을 수 없었기 때문이다.

보존적 치료군과 수술적 치료군 간 독립변수들의 차이를 확인하기 위한 분석방법으로 교차분석을 사용하였고, 각각 의 독립변수 중 표본 수가 5 이하인 경우가 $20 \%$ 이상인 경우 에는 Fisher's Exact test, 이하인 경우에는 $\chi^{2}$ 검정을 사용하 였다. 따라서 $\chi^{2}$ 검정은 증상 발생 후 치료 시작까지 소요시 간, 말초 혈액 백혈구 수, 적혈구 침강속도, $\mathrm{C}$-반응단백, 당뇨, 고혈압 유병률 차이를, Fisher's Exact test는 연령을 분석하 
는 데 이용되었다. 다중 회귀 분석(multiple regression analysis) 시 종속 변수인 치료방법 선택에 영향을 미치는 변수들 로 연령, 증상 발현부터 입원까지 소요시간, 고혈압과 당뇨 유 병률, 말초 혈액 백혈구 수, 적혈구 침강속도, $\mathrm{C}$-반응단백 수 치를 조사하였으며 SPSS 12.0 프로그램(SPSS Inc., Chicago, IL, USA)을 이용하였다.

\section{결 과}

\section{성별 및 연령 분포}

성별은 보존적 치료군에서 남자가 28명(50\%)이었으며, 수술 적 치료군에서는 남자가 17 명(53\%)이었다. 평균 연령은 보존
적 치료군에서 $47 \pm 15$ 세, 수술적 치료군에서 $53 \pm 22$ 세로 단 변량 분석에서는 통계적으로 유의한 연령의 차이를 보였으나 다변량 분석에서는 통계적으로 유의한 차이를 보이지 않았 다. 연령별 분포는 보존적 치료군에서 40대 환자가 가장 높은 빈도를 보였고 수술적 치료군에서는 연령별로 고른 분포를 보였다(Table 1).

\section{증상 발생 후 입원까지 소요 시간, 기저질환 유무}

증상 발생 후 입원까지의 평균 기간은 보존적 치료군에서 $4 \pm 3$ 일, 수술적 치료군에서 $4 \pm 4$ 일이었고 통계적으로 유의한 차이를 보이지 않았다(Table 1). 통계에 포함시키지는 않았으 나 평균 입원 기간은 보존적 치료군에서 $8 \pm 4$ 일, 수술적 치료

Table 1. Demographic and clinical characteristics of the patients and univariate analysis for possible contributing predictors to determine the surgical treatment option between conservative treatment group and surgical treatment group in patients with deep neck infection

\begin{tabular}{|c|c|c|c|}
\hline & Conservative treatment group $(n=56)(\%)$ & Surgical treatment group $(n=32)(\%)$ & p-value \\
\hline Male & $28(50.0)$ & $17(53.1)$ & 0.465 \\
\hline Age (years) & & & 0.004 \\
\hline$<29$ & $7(12.5)$ & $3(9.4)$ & \\
\hline $30-39$ & $6(10.7)$ & $6(18.8)$ & \\
\hline $40-49$ & $24(42.9)$ & $5(15.6)$ & \\
\hline $50-59$ & $11(19.6)$ & $4(12.5)$ & \\
\hline $60-69$ & $4(7.1)$ & $6(18.8)$ & \\
\hline $70-79$ & $4(7.1)$ & $4(12.5)$ & \\
\hline$>80$ & 0 & $4(12.5)$ & \\
\hline Average & $47 \pm 15$ & $53 \pm 22$ & \\
\hline $\begin{array}{l}\text { Duration from symptom onset } \\
\text { to hospitalization (day) }\end{array}$ & & & 0.841 \\
\hline$<3$ & $35(62.5)$ & $19(59.3)$ & \\
\hline $4-7$ & $17(30.4)$ & $10(31.3)$ & \\
\hline$>7$ & $4(7.1)$ & $3(9.4)$ & \\
\hline Average & $4 \pm 3$ & $4 \pm 4$ & \\
\hline WBC (cells $\left./ \mathrm{mm}^{3}\right)$ & & & 0.150 \\
\hline$<10000$ & $11(19.6)$ & $4(12.5)$ & \\
\hline $10000-15000$ & $27(48.2)$ & $14(43.8)$ & \\
\hline$>15000$ & $18(32.2)$ & $14(43.8)$ & \\
\hline Average & $13797 \pm 1152$ & $15927 \pm 1233$ & \\
\hline $\mathrm{ESR}(\mathrm{mm})$ & & & 0.086 \\
\hline$<20$ & $10(16.0)$ & $2(6.2)$ & \\
\hline $20-40$ & $19(30.2)$ & $7(21.9)$ & \\
\hline$>40$ & $27(42.8)$ & $23(71.9)$ & \\
\hline Average & $39 \pm 17$ & $55 \pm 26$ & \\
\hline CRP $(\mathrm{mg} / \mathrm{dL})$ & & & 0.001 \\
\hline$<10$ & $37(66.0)$ & $8(25.0)$ & \\
\hline $10-20$ & $16(28.6)$ & $6(18.8)$ & \\
\hline$>20$ & $3(5.4)$ & $18(56.2)$ & \\
\hline Average & $9 \pm 6.38$ & $22 \pm 13.66$ & \\
\hline DM & $6(10.7)$ & $8(25.0)$ & 0.054 \\
\hline $\mathrm{HBP}$ & $6(10.7)$ & $17(53.1)$ & 0.001 \\
\hline
\end{tabular}


Predictive Factors of Surgical Treatment of Deep Neck Infection I Sohn JH, et al.

Table 2. Incidence of underlying medical diseases between conservative treatment group and surgical treatment group in patients with deep neck infection

\begin{tabular}{lcc}
\hline & $\begin{array}{c}\text { Conservative } \\
\text { treatment group } \\
(\mathrm{n}=56)(\%)\end{array}$ & $\begin{array}{c}\text { Surgical } \\
\text { treatment group } \\
(\mathrm{n}=32)(\%)\end{array}$ \\
\hline DM & $6(10.7)$ & $8(25.0)$ \\
HBP & $6(10.7)$ & $17(53.1)$ \\
Liver cirrhosis & $1(1.7)$ & 0 \\
Asthma & $1(1.7)$ & 0 \\
Hypothyroidism & $1(1.7)$ & 0 \\
Angina & 0 & $2(6.2)$ \\
Arrhythmia & 0 & $1(3.1)$ \\
COPD & 0 & $1(3.1)$ \\
CVA & 0 & $1(3.1)$ \\
\hline
\end{tabular}

DM: diabetes mellitus, HBP: high blood pressure, COPD: chronic obstructive pulmonary disease, CVA: cerevrovascular accident

Table 3. Multiple regression analysis of possible contributing predictors between conservative treatment group and surgical treatment group in patients with deep neck infection

\begin{tabular}{lccc}
\hline & Odds ratio & $95 \% \mathrm{Cl}$ & p-value \\
\hline Age & 0.855 & $0.642-1.117$ & 0.388 \\
HBP $(\mathrm{n})$ & 1.74 & $1.422-2.260$ & 0.005 \\
DMs $(\mathrm{n})$ & 1.728 & $0.815-5.384$ & 0.510 \\
WBC count $\left(\right.$ cells $\left./ \mathrm{mm}^{3}\right)$ & 1.07 & $0.794-1.224$ & 0.847 \\
ESR $(\mathrm{mm})$ & 1.18 & $1.008-1.342$ & 0.302 \\
CRP $(\mathrm{mg} / \mathrm{dL})$ & 1.48 & $1.119-1.780$ & 0.003 \\
\hline
\end{tabular}

Cl: confidence interval, HBP: high blood pressure, DM: diabetes mellitus, WBC: white blood cell count, ESR: erythrocyte sedimentation rate, CRP: C-reactive protein

군에서 $14 \pm 7$ 일로 수술적 치료군에서 더 높았다.

기저질환을 살펴보면 보존적 치료군에서 고혈압이 3명, 당 뇨가 3명, 고혈압과 당뇨를 모두 가진 환자가 3명이었으며 간 경화, 천식, 갑상선 기능 저하증을 가진 환자가 각각 1 명이었 다. 수술적 치료군에서는 고혈압이 10 명, 당뇨가 1 명, 고혈압 과 당뇨를 모두 가진 환자가 6명이었으며, 고혈압과 당뇨 그리 고 협심증을 가진 환자가 1 명, 부정맥을 가진 환자가 1 명, 협 심증과 만성 폐쇄성 폐 질환을 가진 환자가 1 명, 뇌혈관 질환 을 가진 환자가 1 명이었다(Table 2). 통계처리를 하였을 때 단 변량 분석에서 고혈압이 존재할 시 수술적 치료가 필요했던 경우가 유의하게 높았고 다변량 분석에서도 Odds ratio 1.74 $(p=0.005)$ 로 유의하게 높았다(Table 3). 당뇨 환자는 수술적 치료군에서 더 높은 빈도를 보였으나 두 가지 분석 모두에서 통계적으로 유의한 차이는 없었다(Table 1 and 3).

말초 혈액 백혈구 수, 적혈구 침강속도, C-반응단백 수치

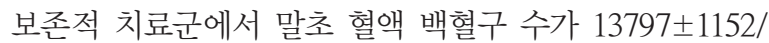
$\mathrm{mm}^{3}$ 이었고 수술적 치료군에서 $15927 \pm 1233 / \mathrm{mm}^{3}$ 로 더 높았
Table 4. Comparison of involved deep neck infection spaces between conservative treatment group and surgical treatment group

\begin{tabular}{lcc}
\hline Space & $\begin{array}{c}\text { Conservative } \\
\text { treatment group } \\
(\mathrm{n}=56)(\%)\end{array}$ & $\begin{array}{c}\text { Surgical } \\
\text { treatment group } \\
(\mathrm{n}=32)(\%)\end{array}$ \\
\hline $\mathrm{PP}$ & $29(51.8)$ & $14(43.8)$ \\
$\mathrm{RP}$ & $3(5.4)$ & $0(0.0)$ \\
$\mathrm{PP}+\mathrm{RP}$ & $23(41.1)$ & $14(43.8)$ \\
$\mathrm{PP}+$ pretracheal & $1(1.8)$ & $4(12.5)$ \\
\hline Total & $56(100)$ & $32(100)$ \\
\hline
\end{tabular}

PP: parapharyngeal, RP: retropharyngeal

으나 두 군간 통계적 유의성은 없었다. 적혈구 침강속도는 보 존적 치료군에서 $39 \pm 17 \mathrm{~mm}$, 수술적 치료군에서 $55 \pm 26 \mathrm{~mm}$ 였으나 유의한 차이를 보이지 않았으며 C-반응단백 수치는 보존적 치료군에서 $9 \pm 6.38 \mathrm{mg} / \mathrm{dL}$, 수술적 치료군에서 $22 \pm$ $13.66 \mathrm{mg} / \mathrm{dL}$ 로 단변량 분석에서 수술적 치료군이 유의하게 높게 측정되었고 $(p=0.001)$ 다변량 분석에서도 Odds ratio 1.48 $(p=0.003)$ 로 유의한 차이를 보였다(Table 1 and 3).

\section{침범된 경부 공간}

보존적 치료군에서는 인두주위강(parapharyngeal space) 에서 29예(51.8\%), 후인두 공간(retropharyngeal space)에서 3예(5.4\%), 인두주위강과 후인두 공간을 함께 침범한 경우가 23예(41.1\%), 인두주위강과 전 기관강(pretracheal space)을 동시에 침범한 경우가 1 예(1.8\%)로 인두주위강을 침범한 경우 가 가장 많았다. 한편 수술적 치료군에서는 인두주위강에서 14 예(43.8\%), 인두주위강과 후인두 공간을 함께 침범한 경우 가 14 예(43.8\%), 인두주위강과 전기관강을 같이 침범한 경우 가 4예(12.5\%)였다(Table 4).

\section{고 찰}

심경부 감염은 경부 근막강내 염증이 파급되어 농양을 형성 하는 것을 말한다. 항생제 사용 이전에는 심경부 감염의 약 $70 \%$ 가 인두 또는 편도 감염의 파급으로 인해 초래되었으나, 항생제 사용 이후에는 치성 또는 타액선 감염의 파급이 증가 하는 추세이다. ${ }^{6}$ 치성 원인은 보고자에 따라 약 $37.5 \%$ 에 이 르고 있으나 국내 연구에서는 여전히 구인두 감염의 비중이 치성 감염보다 높은 것으로 판단하고 있다.

심경부 감염의 진단을 위해서는 경부를 면밀히 시진, 촉진 한 뒤 내시경을 통한 인후두 점막 염증, 부종, 기도폐쇄 정도 를 평가하는 것이 필수적이다. 또한 내원 즉시 전 혈구 수치, 간기능검사와 신장기능검사, 혈당, 적혈구 침강 속도, $\mathrm{C}-$ 반응 단백 수치를 포함한 혈액 검사를 실시하며 방사선학적 검사 
로는 조영증강 경부 전산화단층촬영이 필수적이다. 심경부 감염이 진단되면 균 배양검사 여부에 관계없이 경험적 광범 위 항생제를 사용하는데, 적극적인 내과적 치료를 시행함에 도 임상 증상의 호전이 없을 시 경경부 절개 배농을 시행하 는 것이 보편화되어 있다. 저자들은 서론에서 기술한 바와 같이 내원 당시 경부 전산화단층촬영상 명백한 농양이 확인 됨에도 항생제를 비롯한 보존적 치료만으로 완치되는 경우 를 임상에서 드물지 않게 경험할 수 있는 반면, 보존적 치료 에 반응하지 않아 경경부 절개 배농과 괴사조직 제거 등의 적극적인 수술치료가 필요한 경우도 흔히 경험함으로써, 두 군 간의 어떠한 임상적 차이가 있는지 연구하게 되었고, 치료 에 영향을 미치는 여러 인자들을 종합적으로 평가하고자 단 변량 분석과 다변량 분석을 모두 실시하였다. 통계를 이용하 여 정확한 결과를 얻기 위해 가장 중요하고 어려운 부분은 충분한 수의 증례를 확보하는 것인데 본 연구에 포함된 대상 의 수는 6년간 88예로서 표본이 매우 크다고 할 수는 없다. 하지만 경부 농양의 크기가 크고 합병증이 동반된 중증 환 자들과 편도주위 농양과 표재성 농양 같은 경증환자들을 제 외하고 엄격하게 연구대상을 선별하도록 노력하였다.

두 군 간의 비교 결과에서 단변량 분석을 사용했을 경우에 는 연령, C-반응단백 수치, 고혈압 유병률이 유의한 차이를 보였으나 다변량 분석을 사용한 결과는 C-반응단백과 고혈 압 유병률만이 유의한 차이를 보이는 것으로 나타났다. 수술 적 치료군의 평균 $\mathrm{C}$-반응단백 수치는 보존적 치료군보다 2.4 배 이상 높았으며 odds ratio는 1.48 이었다. C-반응단백은 급 성기 반응물질 중 하나로 감염, 손상, 수술, 외상, 조직 괴사 시 증가하며 연쇄상구균의 C-polysaccharide와 침강반응을 일으키는 성질에 의해 C-반응단백으로 명명되었는데 급성기 반응물질 중 가장 먼저 증가하고 치료 시 가장 먼저 정상화되 는 특징을 가지고 있으며 정상수치 $(0.3 \sim 1 \mathrm{mg} / \mathrm{dL}$ 이하)의 1000 배까지도 증가된다고 알려져 있다. ${ }^{8)}$ 이러한 특성으로 인해 술 후 염증 반응의 추적, 잠재감염의 확인, 자가면역질환의 질병 활성도 평가에 이용되고 있으며 심경부 감염뿐 아니라 신체 대부분의 부위에서 발생한 심부 감염과 포도상구균 균혈증 조기 발견의 예측 인자로도 사용된다.")

반면, 심경부 감염에서 고혈압이 미치는 영향에 대해서 연구 한 논문은 찾기 어려우며 심혈관계, 호흡기계 질환이 동반된 심경부 감염 환자들에서 종격동염으로의 이행이 더 빈번했다 는 연구는 찾을 수 있다. ${ }^{10)}$ 저자들은 단변량, 다변량 분석 모 두에서 고혈압이 유의한 결과로 나타난 것은 수술적 치료군 의 평균 연령이 높은 것이 반영된 것으로 이에 따른 고혈압 유병률이 차이를 보이는 것이라고 추측하였다. 결과에서 보듯 두 군 사이의 연령차는 5 세 정도로 단변량 분석에서는 통계적
으로 유의한 차이를 보인 바 있다.

결과에서 통상적인 추측과 차이를 보이는 점은 당뇨병 유병 률이 두 군에서 유의한 차이를 보이지 않은 것인데, 당뇨와 세균 감염, 합병증의 연관성에 대해서 다수의 연구들이 보고 되어 온 것을 감안하면 의외의 결과라 할 수 있다. 이전 연구를 살펴보면 불량한 혈당 조절이 중성구 살균 기능을 저하한다 고 알려지며, 고혈당이 세포매개면역과 보체 활성화를 저하 시키는 것으로 보고되고 있다. ${ }^{11-13)}$ 또한 심경부 감염에 관해 서도 당뇨병을 가진 환자에서 감염에 취약하여 합병증 발생 률이 높으면서 입원 기간이 증가되고 ${ }^{14,15}$ 감염이 경부의 여러 공간을 침범할 가능성이 높고 연쇄상구균류(Streptococcus spp.)보다 폐렴간균(Klebsiella pneumonia) 감염 빈도가 높 다는 체계적 메타분석(systematic review and meta-analysis) 도 찾을 수 있다. ${ }^{16)}$ 다수의 보고에도 불구하고 본 연구에서 당뇨병이 유의한 인자로 나오지 않은 것에 대해 저자들은 다 음과 같이 추측하였다. 첫 번째, 당뇨병 환자는 심경부 감염 진단 시 합병증을 유발했거나 염증의 정도가 심하여 조기에 수술을 시행하게 되어 연구대상에 포함되지 않았을 가능성 이 있다고 판단하였고 두 번째, 두 군간 평균연령 차이가 있 음에도 고혈압은 두 군간 유병률 차이가 있는데 당뇨병은 유 병률 차이를 보이지 않은 것이 원인으로 생각되었는데 앞서 기술한 바와 같이 장기간 증례를 모았음에도 표본 수가 매우 많지는 않은 것이 제한점이 아닐까 생각된다.

입원 기간을 변수의 하나로 사용하는 것도 생각할 수 있고 입원 기간이 길어지는 것이 감염의 중증도를 나타내는 지표 로 사용될 수 있다고 생각되나, 보존적 치료군과 수술적 치 료군을 나누어 진행하는 연구에서는 근본적으로 입원 기간 의 차이가 날 수밖에 없으므로 비교 대상에서 제외하였다. 그 외에도 여러 경부 공간을 동시에 침범하는 경우 일반적으로 수술적 치료가 필요하다고 알려져 있는데, 이 또한 임상적으 로 대부분 조기에 수술적 치료가 행해지게 되므로 변수로 포 함하지 않았다. 본 연구의 결과 중 간과해서 안 되는 중요한 사항은 심경부 감염 수술적 치료의 영향 인자로서 고혈압과 $\mathrm{C}$-반응단백이 유의하였으나 당뇨병이 유의하지 않게 나온 점으로, 다수의 연구에서 입증된 것처럼 당뇨를 가진 심경부 감염 환자들 중에 심한 세균감염을 가지거나 합병증이 발생 한 경우가 많아 조기에 절개 배농이 행해졌으므로 연구 대상 군에서 제외되었을 가능성이 높아 조기에 수술적 치료를 행 한 심한 감염 환자들을 포함한다면 결과가 달라질 가능성이 있다고 생각된다. 심경부 감염 환자의 치료 방향은 환자의 임 상 증상과 혈액 검사 소견, 영상학적 검사 등을 고려해서 적 절하고 신속하게 결정되어야 하며 본 연구의 결과가 보다 좋 은 임상 결과를 얻는데 참조가 되었으면 한다. 
결론적으로, $\mathrm{C}-$ 반응단백과 고혈압 유병률이 심경부 감염 환자에서 수술적 치료를 결정하는 데 유의한 예측 인자로 판 단된다. 당뇨병 유병률은 본 연구에서 심경부 감염 치료방법 선택의 예측 인자로 판단되지는 않았다.

\section{REFERENCES}

1) Colmenero Ruiz C, Labajo AD, Yañez Vilas I, Paniagua J. Thoracic complications of deeply situated serous neck infections. J Craniomaxillofac Surg 1993;21(2):76-81.

2) Beck HJ, Salassa JR, Mccaffrey TV, Hermans PE. Life-threatening soft tissue infections of the neck. Laryngoscope 1984;94(3):354-62.

3) Chen MR, Wen YS, Hsiao HC. Thoracic complications of deep neck infection report of four cases. J Otolaryngol Soc Taiwan 1997;32: 454-8.

4) Estrera AS, Landay MJ, Grisham JM, Sinn BP, Platt MR. Descending necrotizing mediastinitis. Surg Gynecol Obstet 1983;157:545-52.

5) Cho KR, Yoo YS. [Clinical characteristics of medically intractable deep neck infection patients]. Korean J Otorhinolaryngol-Head Neck Surg 2009;52(1):62-6.

6) Hwang EG, Jeon SY, Hong SK, Ma YW, Kim NJ, Kim HJ, et al. [A comparative study of odontogenic and non-odontogenic deep neck infections]. Korean J Otorhinolaryngol-Head Neck Surg 1992;35 (3):403-9.

7) Do NY, Cho SI, Lee JH, Dong GW, Kim GH. [Clinical study of deep neck infection]. Korean J Otolaryngol-Head Neck Surg 2007;50(3): 240-6.

8) Korean society of clinical pathology. Clinical pathology. 1st ed. Seoul,
Korea: Korea med;1994. p.279-80.

9) Mölkänen T, Ruotsalainen E, Rintala EM, Järvinen A. Predictive value of C-reactive protein (CRP) in identifying fatal outcome and deep infections in Staphylococcus aureus bacteremia. PLoS One 2016;11(5):e0155644.

10) Celakovsky P, Kalfert D, Tucek L, Mejzlik J, Kotulek M, Vrbacky A, et al. Deep neck infection: risk factors for mediastinal extension. Eur Arch Otorhinolaryngol 2014;271(6):1679-83.

11) Gallacher SJ, Thomson G, Fraser WD, Fisher BM, Gemmell CG, MacCuish AC. Neutrophil bactericidal function in diabetes mellitus: evidence for association with blood glucose control. Diabet Med 1995;12(10):916-20.

12) Delamaire M, Maugendre D, Moreno M, Le Goff MC, Allannic H, Genetet B. Impaired leukocyte functions in diabetic patients. Diabet Med 1997;14(1):29-34.

13) MacCuish AC, Urbaniak SJ, Campbell CJ, Duncan LJ, Irvine WJ. Phytohemagglutinin transformation and circulating lymphocyte subpopulations in insulin-dependent diabetic patients. Diabetes 1974; 23(8):708-12.

14) Huang TT, Tseng FY, Liu TC, Hsu CJ, Chen YS. Deep neck infection in diabetic patients: comparison of clinical picture and outcomes with nondiabetic patients. Otolaryngol Head Neck Surg 2005;132(6): 943-7.

15) Lee JK, Lim SC. [Deep neck infections in diabetic patients]. Korean J Otorhinolaryngol-Head Neck Surg 2006;49(3):323-7.

16) Hidaka H, Yamaguchi T, Hasegawa J, Yano H, Kakuta R, Ozawa D, et al. Clinical and bacteriological influence of diabetes mellitus on deep neck infection: systematic review and meta-analysis. Head Neck 2015;37(10):1536-46. 